\title{
Malignant peripheral nerve sheath tumor of the prostate
}

\author{
Boleslaw Kuzaka, Slawomir Poletajew, Tomasz Borkowski, \\ Jacek Borowski, Piotr Radziszewski
}

\begin{abstract}
The diagnostic and therapeutic approach to prostatic neurosarcoma, currently known as a malignant peripheral nerve sheath tumor (MPNst) of the prostate, due to its rarity, is not well established. Our presenting case was a 73 year old patient, admitted to the Hospital with suspicion of a prostatic tumor. The patient underwent surgical resection of the described pathological mass. Gross appearance of the pathological examination revealed a yellow-gray colored tumor, $12 \times 6 \times 7 \mathrm{~cm}$ in size. On cross-section: tumor heterogeneity, fatty, yellow-gray, with no foci of necrosis, but with a few cysts of $1-3 \mathrm{~cm}$ in size, with a gelatinous substance. Microscopic examination - showed neurosarcoma of the prostate. The patient died at six months follow-up, due to cardiovascular insufficiency.
\end{abstract}

\section{Złośliwy nowotwór osłonek nerwów obwodowych o umiejscowieniu w sterczu}

Postępowanie diagnostyczne i terapeutyczne u pacjentów z nerwiakomięsakami prostaty (aktualnie klasyfikowanymi jako złośliwe nowotwory osłonek nerwów obwodowych) pozostaje nieokreślone z powodu rzadkiej na nie zapadalności. Przedstawiamy przypadek 73-letniego chorego, przyjętego do szpitala z powodu nowotworu stercza, który został poddany wycięciu zmiany. Makroskopowo stwierdzono żółto-szarawy guz o wymiarach $12 \times 6 \times 7 \mathrm{~cm}$, na przekroju o niejednorodnej budowie z zawartością tkanki tłuszczowej, bez ognisk martwicy, ale z obecnością kilku torbieli o wymiarach 1-3 cm, wypełnionych treścią galaretowatą. Badanie mikroskopowe ujawniło cechy nerwiakomięsaka. Pacjent zmarł sześć miesięcy po operacji w następstwie niewydolności krążenia.

NOWOTWORY Journal of Oncology 2015; 65, 2: 139-143

Key words: prostatic neoplasms, MPNSTs, enucleation

Słowa kluczowe: nowotwór prostaty, złośliwy nowotwór osłonek nerwów obwodowych, wyłuszczenie

\section{Introduction}

Malignant peripheral nerve tumors, which include neurosarcoma derived from Schwann-Cells, are described in the literature under different names: schwannoma malignum, neurilemmoma malignum or sarcoma neurogenes. Currently, this cancer is usually described in the anglo-saxon literature as a malignant peripheral nerve sheath tumor (HPNSts), occurring on the limbs or neck. Other locations, including retroperitoneal, associated with a bunch of cerebrovascular nerve are rare. The aim of this paper is to briefly present a very unusual case of prostatic localization of the tumor.

\section{Case report}

A 73 year old patient, was admitted to the Hospital with suspicion of a prostatic tumor. The patient reported pain around the sacrum and disturbances in passing stool, urine flow impairment, nocturia $1 \times$ for about one year in duration. There was no urinary retention or hematuria. The level of PSA was $1.15 \mathrm{ng} / \mathrm{ml}$. Performed biopsy of the prostate revealed normal prostate tissue. Intravenous urography (figure 1) showed an irregular mass modelling the right upper wall of the bladder. An ultrasound scan showed a solid structure measuring about $100 \mathrm{~mm}$ at the right-hand-side posterior bladder wall (cross section figure 2 ).

Department of Urology

Medical University of Warsaw, Poland 


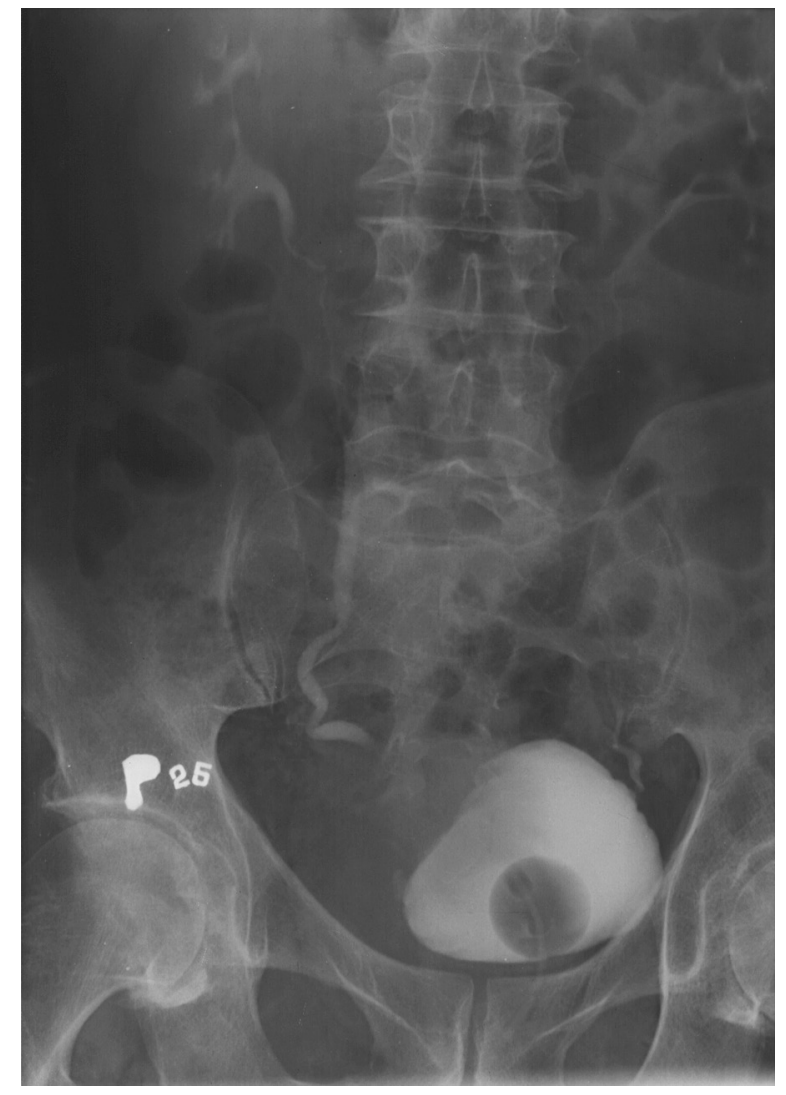

Figure 1. Urography. Displacement of the bladder to the left, and modelling of the upper-right side of its wall. Upward displacement and bending of the lower part of the right ureter

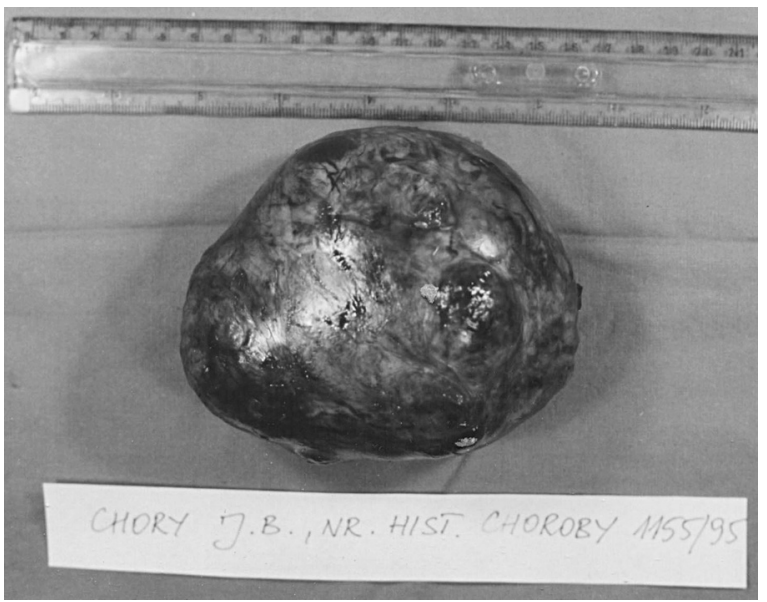

Figure 3. Elastic, yellow-gray tumor $12 \times 6 \times 7$ in diameter

The patient underwent surgical resection of the described pathological mass. A tumor of about $120 \mathrm{~mm}$ in diameter was found between the rectum and bladder wall with a clear lateralization of the right side. The cecum was manually moved away upwards, the peritoneum was incised over the tumor and a fairly easy cleavage plan appeared. The tumor was enucleated without any major problems. However major bleeding from perirectal and peribladder veins occurred. During management to stop the bleeding, the right ureter was knowingly "en masse" punctured to facilitate

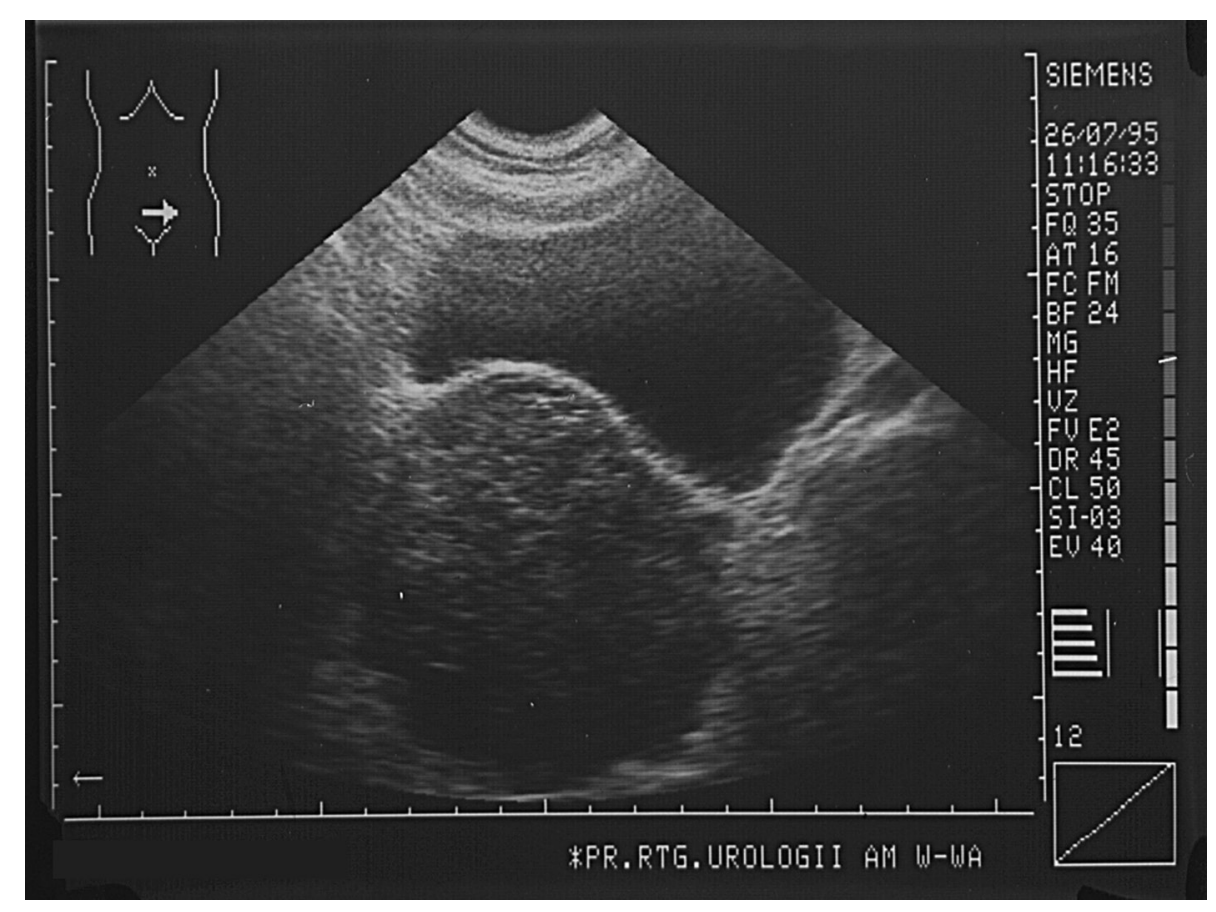

Figure 2. US-scan. Transverse section of the small pelvis. The solid tumor about $100 \mathrm{~mm}$ long at the posterior wall of the right-side of the bladder 


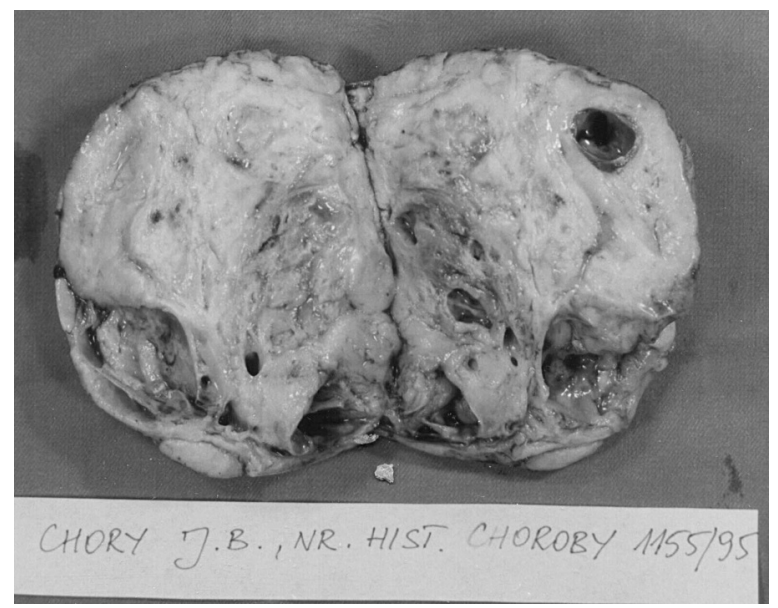

Figure 4. On the cross-section: heterogenic tumor, fatty, yellow-gray, with no foci of necrosis, with few cysts $1-3 \mathrm{~cm}$ in size, the gelatinous substance in the largest one, clearly to stratify, quite thick bag with numerous vessels

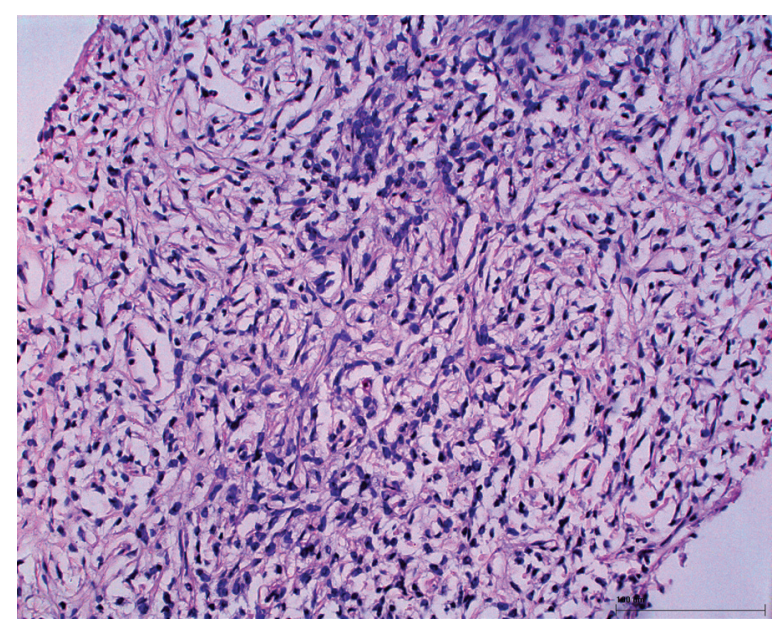

Figure 5. Neurosarcoma weaving of delicate, elongated cells, with the presence of atypical cells. HE Staining

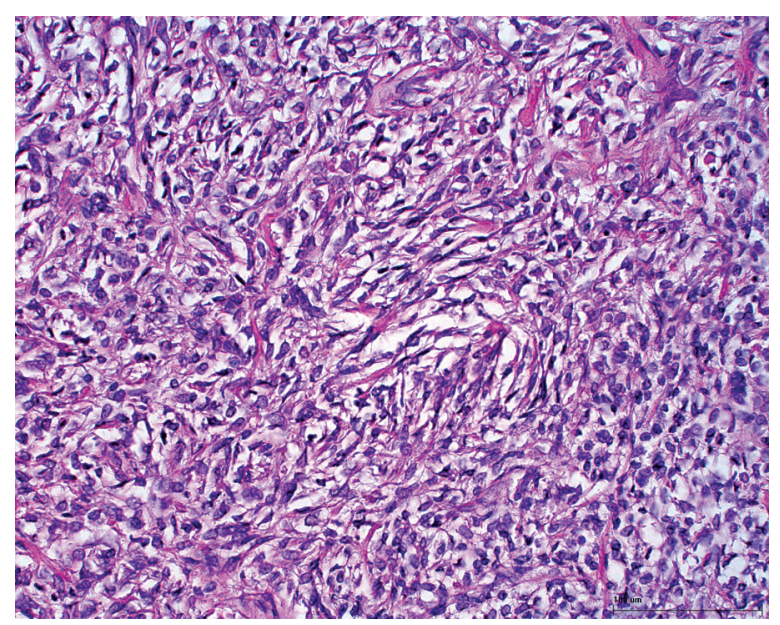

Figure 6. Hypercellular neurosarcoma texture. HE Staining

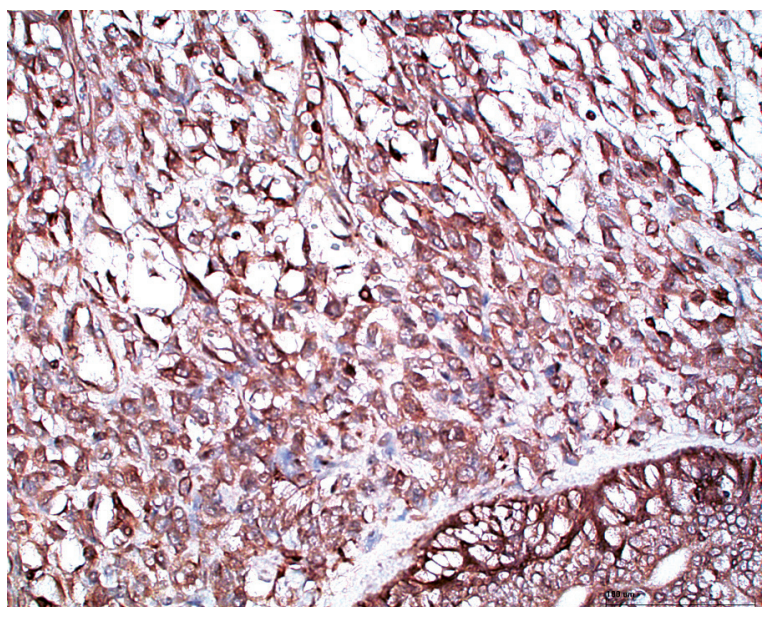

Figure 7. Immunohistochemical reaction for S-100

hemostasis. In the next step, the bladder was opened. The ureter was cut over the puncture and was transplanted to the bottom of the bladder. The postoperative course was complicated by the left epididymitis, which was managed by gentamycin administration. The patient was discharged with a mild urinary incontinence. The patient died at six months follow-up, probably due to cardiovascular insufficiency.

Gross appearance of the pathological examination revealed a yellow-gray colored tumor, $12 \times 6 \times 7 \mathrm{~cm}$ in size (figure 3). On cross-section: tumor heterogeneity, fatty, yellow-gray, with no foci of necrosis, but with a few cysts of $1-3 \mathrm{~cm}$ in size, with the gelatinous substance in the largest one, clearly to stratify, quite thick bag with numerous vessels (figure 4). Tissue material (clippings) was developed routinely, using staining with hematoxylin and eosin and silver plating according to the Gomori formula and immunohistochemical study of S-100 (a protein specific to the nervous system) (figures 5, 6, 7). Microscopic examination - showed Neurosarcoma of the prostate.

\section{Discussion}

Neurosarcomas, are described in the literature under different names: schwannoma malignum, neurilemmoma malignum or sarcoma neurogenes. According to Andrew L. Folpe and Carrie Y. Inwolds (Bone and soft tissue pathology 2010, Elsevier Inc.) soft tissue sarcomas have been linked within families, so it is hypothesized that neurofibrosarcoma may be genetic, although researchers still do not know the exact cause of the disease. Evidence supporting this hypothesis includes loss of heterozygosity on the $17 p$ chromosome. The p53 (a tumor suppressor gene in the normal population) genome on $17 p$ in neurofibrosarcoma patients is mutated, increasing the probability of cancer. The normal p53 gene will regulate cell growth and inhibit any uncontrollable cell growth in the healthy population; since 
p53 is inactivated in neurofibrosarcoma patients, they are much more susceptible to developing tumors.

Patients with NF1 experience development of MPNSTs at earlier ages. NF1-associated MPNST accounts for between $50 \%$ and $67 \%$ of cases. A marked male predominance is seen with both sporadic and NF1-associated tumors. Currently, in the anglo-saxon literature this neoplasm is usually described as a malignant peripheral nerve sheath tumor (MPNSts). They belong to the group of malignant peripheral nerve sheath tumors (MPNST), highly malignant, infrequent soft tissue sarcomas of ectomesenchymal origin. The exact cell origin for these tumors has not been definitively confirmed yet, however it is known that neurosarcomas arise from major and minor peripheral branches or their sheaths [1]. Carcinogenesis in MPNSTs concerns mostly a suppressor NF1 gene aberration. Its product, neurofibromin, reduces proliferation of cells by inactivation of the protooncogene p21-ras [2]. Malignancies are locally invasive, may lead to reoccurrence, as well as metastatic spread. The most common location is the sciatic nerve, followed by the brachial plexus; spinal nerve roots; the vagus, femoral, sacral plexus, popliteal, obturator, posterior tibial, and ulnar nerves; and the vulva, posterior mediastinum, or retroperitoneal location [3].

Diagnosis of MPNST is usually based on one or more of following criteria:

1) association with peripheral nerve,

2) transformation of preexisting neurofibroma,

3) positive immunohistochemical reaction when using antibodies against peripheral nerve antigens [4].

Macroscopically they are fusiform, white masses, sometimes with hemorrhagic foci (especially in larger tumors). Microscopically the histologic differentiation is usually poor. The tumor is non-encapsulated, composed of spindle cells with comma-shaped nuclei, infiltrating the axis of the parent nerve and/or adjacent soft tissues. Degeneration effects are commonly observed, as necrosis or cyst formation. In 15\% epithelioid components may also be seen [5].

For microscopic examination standard staining is used (hematoxylin-eosin and reticulin), as well as immunohistochemical staining for final diagnostic confirmation. The mature Schwann cell marker S-100 is most prominent, however others are also used: desmin, myogenin, MIB-1 proliferation marker, Leu-7 myelin-associated glycoprotein, vimentin, myelin basic protein. Positive reaction with S-100 protein is observed in $50-90 \%$ of MPNST $[6,7]$.

Tumor size defines staging, while atypia and mitotic activity defines grading of MPNST [8]. 5 centimeters is used as a border diameter of MPNST for prognostic purposes. Larger tumors are more often high grade, inoperable in terms of oncological radical surgery, and relatively frequently present with neurological deficits [4, 9-11]. For three-step grading (GI-GIII), the same criteria as for other tissue sarcomas, are used, thus cellularity, mitotic activity, cellular as well as nuclear atypia and anaplasia.

In general, patients with MPNSTs have a poor prognosis. Five-year overall survival is reported to be as low as 16-52\% [12-14]. Even with aggressive surgical and adjuvant therapy, local recurrence is diagnosed in $50 \%$ of cases [15]. The main reason for death is hematogenous spread to the lungs, less commonly to the liver, brain, soft tissue, bones, regional lymph nodes, skin or retroperitoneum [14].

Neurovascular tumor of the prostate is a very rare tumor [16]. In the 61 years of material at our clinic it is the first case. The diagnosis is based on histopathological examination. Surgical treatment is the first step. More often adjuvant therapy is warranted (e. g radiotherapy). The prognosis is uncertain [16]. Reoccurrence is often, especially in non-radical surgical procedures [16]. This case is presented because of the rarity of occurrence, difficult choice of treatment, and uncertain prognosis.

Our patient had a multiple cutaneous lesions (tubercle) on the shoulder and neck similar to a neurofibromatosis. Due to emergency related with necessity of resolving the case of prostate tumor, at the beginning we decided to perform only a surgical enucleation of the prostate tumor. After performed surgery the patient was discharged from the clinic after 3 weeks and did not return for the following diagnostic (biopsy of tubercules) and treatment procedures. He died after 6 months at home due to cardiac insufficiency. There was no history of malignancy in the family.

\section{Bolesław Kuzaka MD, PhD}

Department of General, Oncological and Functional Urology Medical University of Warsaw

PL 02-005 Warszawa, 4 Lindleya St. e-mail:boleslaw.kuzaka@wum.edu.pl

Paper received: 16 September 2014

Accepted: 15 January 2015

\section{References}

1. Wanebo JE, Malik JM, VandenBerg SR et al. Malignant peripheral nerve sheath tumors. A clinicopathologic study of 28 cases. Cancer 1993; 71: 1247-1253.

2. Woodruff JM. Arthur Purdy Stout and the evolution of modern concepts regarding peripheral nerve sheath tumors. Am J Surg Pathol 1986; 10 (1 Suppl):63-67.

3. Topsakal C, Akdemir I, Tiftikci M et al. Malignant schwannoma of the sciatic nerve originating in a spinal plexiform neurofibroma associated with neurofibromatosis type 1-case report. Neurol Med Chir 2001;41:551-555.

4. Angelov L, Davis A, O'Sullivan B et al. Neurogenic sarcomas: experience at the University of Toronto. Neurosurgery 1998; 43: 56-65.

5. Guo A, Liu A, Wei L et al. Malignant peripheral nerve sheath tumors: differentiation patterns and immunohistochemical features - a mini-review and our new findings. J Cancer 2012; 3: 303-309.

6. Bhattacharyya AK, Perrin R, Guha A. Peripheral nerve tumors: management strategies and molecular insights. JNeurooncol 2004; 69: 335-349.

7. Johnson MD, Glick AD, Davis BW. Immunohistochemical evaluation of Leu-7, myelin basic-protein, S100-protein, glial fibrillary acidic-protein, and LN3 immunoreactivity in nerve sheath tumors and sarcomas. Arch Pathol Lab Med 1988; 112: 155-160.

8. Gupta G, Maniker A. Malignant peripheral nerve sheath tumors. Neurosurg Focus 2007; 22: E12. 
9. LeVay J, O'Sullivan B, Catton C et al. Outcome and prognostic factors in soft tissue sarcomas in the adult. Int J Radiat Oncol Biol Phys 1993; 27: 1091-1099.

10. Pisters PW, Leung D, Woodruff J et al. Analysis of prognostic factors in 1,041 patients with localized soft tissue sarcomas of the extremities. J Clin Oncol 1996: 14: 1679-1689.

11. Saddegh MK, Lindholm J, Lundberg A et al. Staging of soft-tissue sarcomas. Prognostic analysis of clinical and pathological features. J Bone Joint Surg Br 1992; 74: 495-500.

12. Wong WW, Hirose T, Scheithauer BW et al. Malignant peripheral nerve sheath tumor: analysis of treatment outcome. Int J Radiat Oncol Biol Phys 1998; 42: 351-360.
13. Kourea HP, Bilsky MH, Leung DH et al. Subdiaphragmatic and intrathoracic paraspinal malignant peripheral nerve sheath tumors: a clinicopathologic study of 25 patients and 26 tumors. Cancer 1998; 82: 2191-2203.

14. Ducatman BS, Scheithauer BW, Piepgras DG et al. Malignant peripheral nerve sheath tumors. A clinicopathologic study of 120 cases. Cancer 1986; 57: 2006-2021.

15. Murphey MD, Smith WS, Smith SE et al. From the archives of the AFIP. Imaging of musculoskeletal neurogenic tumors: radiologic-pathologic correlation. Radiographics 1999: 19: 1253-1280.

16. Paradysz A, Zyczkowski M, Ziolkowski A et al. [Neurosarcoma pęczka nerwowo-naczyniowego stercza]. Neurosarcoma of the neurovascular bundle of the prostate. Urol Pol 2005; 58: 219-221. 